\title{
OPTIMALISASI SIMDA DALAM MEWUJUDKAN PENGELOLAAN KEUANGAN DAERAH KABUPATEN KUTAI KARTANEGARA PROVINSI KALIMANTAN TIMUR YANG LEBIH BERKUALITAS
}

\section{Simda Optimization in The Making of Financial Management Kutai District East Kalimantan Province To Be More Quality}

\author{
M. Soleh Pulungan \\ Peneliti Balitbangda Kukar Provinsi Kaltim \\ Jl. WR. Mongonsidi Komplek Kantor Bupati Gedung Bappeda-Balitbangda Lt.4, Tenggarong \\ E-mail: solehpulungan66@gmail.com \\ Dikirim: direvisi: disetujui:
}

\begin{abstract}
Abstrak
Tujuan kajian ini adalah untuk mengetahui: 1) Implementasi Simda terhadap pengelolaan keuangan daerah di Kabupaten Kutai Kartanegara; 2) Kesiapan sumber daya manusia yang bertugas mengelola keuangan daerah serta mengetahui permasalahan yang dihadapi; 3) Dukungan dan fungsi Infrastruktur terhadap implementasi Simda di Kabupaten Kutai Kartanegara. Penelitian ini bersifat survey dengan pendekatan penelitian bersifat deskriptif evaluative. Populasi penelitian terdiri dari 18 kecamatan dengan sample penelitian berjumlah 15 kecamatan, yang ditetapkan secara purposive sampling. Hasil kajian Implementasi Simda di Kutai Kartanegara relatif telah cukup tinggi. Semua produk Simda dapat dilakukan diatas rata-rata standard yang ditetapkan regulasi. Kesiapan sumber daya manusia terhadap implementasi Simda di relatif cukup baik. Dukungan jaringan terhadap implementasi Simda sudah cukup tinggi. Software Simda diakui cukup bagus, namun cukup rentan dengan serangan virus.

Kata kunci: Simda, keuangan, implementasi, jaringan, regulasi
\end{abstract}

\begin{abstract}
The purpose of this study was to determine: 1) Simda implementation of the financial management area in Kutai regency; 2) Readiness of human resources in charge of managing local finances and knowing the problems faced; 3) Infrastructure and support functions to the implementation Simda in Kutai regency. This study is a survey with a descriptive evaluative research approach. The study population consisted of 18 districts with a total study sample of 15 districts, which are set by purposive sampling. Implementation results of the study in Kutai Kartanegara Simda have relatively high. All products Simda can do above average standards set regulations. Readiness of human resources for the implementation Simda in relatively good. Network support for implementation Simda already high enough. Software Simda admittedly quite good, but is quite vulnerable to virus attacks.
\end{abstract}

Keywords: Simda, financial, implementation, networking, regulation.

\section{PENDAHULUAN}

Tantangan yang dihadapi oleh Pemerintah Daerah dalam reformasi anggaran dan keuangan berdasarkan peraturan Perundang-undangan yang berlaku sangat beragam dan kompleks. Hal ini dapat dimaklumi karena selain peraturan yang belum difahami oleh semua pegawai yang terlibat dalam system pelaporan keuangan daerah, tetapi lebih dari pada itu adalah kesulitan yang diakibatkan oleh keseluruhan siklus keuangan Pemerintah Daerah. Mulai dari pengesahan anggaran sampai pada penyusunan laporan keuangan yang disebabkan oleh kompleksitas peraturan, kurangnya dukungan sumber daya manusia yang berkompeten, lemahnya koordinasi, dan tidak memadainya teknologi yang digunakan.

Beberapa contoh yang lebih spesifik adalah pengetahuan pegawai dalam memahami isi peraturan yang berkaitan pengelolaan keuangan daerah masih tergolong minim, disamping teknologi sistem manajemen keuangan daerah yang dipergunakan (Simda) oleh Kab. Kutai Kartanegara belum didukung perangkat yang memadai dan keterpaduan perancanaan dan penganggaran dan ketepatan waktu tidak sesuai dengan yang diharapkan. Selain itu terjadinya perbedaan persepsi terhadap arah pembangunan yang diwujudkan dalam RAPBD menimbulkan konflik kepentingan antara DPRD dan Eksekutif sehingga pengesahan RAPBD sering tertunda. Oleh sebab itu upaya untuk lebih mempercepat proses pengesahan anggaran baik pihak eksekutif maupun legeslatif harus melakukan pendekatan yang tegas dalam menerapkan langkahlangkah yang diperlukan bagi penyelesaian proses APBD secara efektif, efisien, dan tepat waktu.

Kemampuan pemerintah daerah dalam menangani persoalan-persoalan di atas sudah barang tentu berbeda-

Optimalisasi Simda dalam Mewujudkan Pengelolaan Keuangan Daerah Kabupaten Kutai Kartanegara Provinsi Kalimantan Timur yang Lebih Berkualitas - M. Soleh Pulungan | 269 
beda. Bahkan di beberapa daerah telah melakukan lompatan besar dengan menerapkan prinsip-prinsip pengelolaan keuangan yang baik. Seperti halnya kabupaten Kebumen di Provinsi Jawa Tengah, kota Pare-pare, dan kota Takalar di Sulawesi Selatan, serta kota Banda Aceh Besar di Provinsi Nangroe Aceh Darussalam merupakan contoh pemerintah daerah yang relative maju dalam peningkatan transparansi pengelolaan keuangan. Daerah-daerah tersebut telah menerapkan pendekatan yang komprehensif dan di saat yang bersamaan mereformasi susunan organisasi pengelolaan keuangan serta daya dukung SDM-nya. Sementara Kabupaten Kutai Kartanegara Provinsi Kalimantan Timur menurut audit BPK juga telah berhasil mendapatkan opini Wajar Tanpa Pengecualian (2012).

Dalam rangka mendukung good governance dan clean governance dalam penyelenggaraan otonomi daerah, perlu diselenggarakan pengelolaan keuangan daerah secara professional, terbuka dan bertanggung jawab sesuai dengan aturan pokok yang telah ditetapkan dalam Undang-Undang. Undang-Undang No.17 tahun 2003 tentang keuangan Negara dan Undang-Undang No. 1 tahun 2004 tentang perbendaharaan Negara mewajibkan pemerintah daerah dan satuan kerja perangkat daerah selaku pengguna anggaran untuk menyusun laporan keuangan sebagai pertanggungjawaban keuangan. Laporan keuangan berupa neraca, laporan arus kas, dan catatan atas keuangan harus disajikan sesuai peraturan pemerintah No. 24 tahun 2005 tenttang Standar Akuntansi Pemerintah.

Pemerintah daerah memerlukan system yang dapat menghasilkan laporan keuangan dan informasi keuangan lainnya secara lebih komprehensif yang meliputi informasi mengenai posisi keuangan daerah, kondisi kinerja keuangan, dan akuntabilitas Pemerintah Daerah. System tersebut juga harus mengacu pada Peraturan Pemerintah No. 58 tahun 2005 tentang Pengelolaan Keuangan Daerah dan Peraturan Menteri Dalam Negeri N0. 13 tahun 2006 tentang Pedoman Pengelolaan Keuangan Daerah.

Simda merupakan program aplikasi komputer yaitu suatu program aplikasi yang ditujukan untuk membantu pemerintah daerah dalam pengelolaan keuangan daerahnya secara terintegrasi yang dimulai dari penganggaran, akuntansi, dan pengelolaan keuangan daerahnya. Dengan aplikasi ini, pemda dapat melaksanakan pengelolaan keuangan daerahnya secara terintegrasi, dimulai dari pengenggaran, penata usahaan, hingga akuntansi dan pelaporannya. Dengan demikian output dari aplikasi ini adalah sebagai berikut: 1). Penganggaran: Rencana Kerja Anggaran (RKA), Dokumen Pelaksanaan Anggaran (DPA), APBD beserta perubahannya, dan Surat Penyediaan Dana (SPD); 2). Penatausahaan: Surat Permintaan Pembayaran (SPP),
Surat Perintah Membayar (SPM), Surat Perintah Pencairan Dana (SP2D), Surat Tanda Setoran (STS), beserta register-register, dan formulir-formulir pengendalian lainnya; 3) Akuntansi dan Pelaporan: Jurnal, Buku Besar, Buku Pembantu, Laporan Realisasi Anggaran, Laporan Arus Kas, dan Neraca.

Program aplikasi Simda ini, juga didukung dengan beberapa buku manual, yaitu: Buku manual system dan Prosedur Anggaran, Buku manual system dan Prosedur Penatausahaan, Buku manual system dan Prosedur Akuntansi dan Pelaporan, dan Buku Pedoman Pengoperasian Aplikasi Simda versi 2.1. System pengelolaan keuangan daerah yang berbasis akural memerlukan dukungan program yang mampu mengelola ribuan transaksi secara cepat, tepat, dan akurat serta didukung oleh tersedianya sumber daya manusia yang mampu mengelola system tersebut sehingga menghasilkan capaian target yang maksimal.

Sementara itu dukungan infrastruktur aplikasi Simda masih belum optimal karena tidak semua wilayah SKPD dapat diakses, terutama SKPD yang berada di wilayah kecamatan dan kelurahan. Padahal untuk proses pengelolaan keuangan daerah dengan menggunakan aplikasi Simda harus didukung oleh adanya akses internet.

Berdasarkan uraian di atas, proses pengelolaan keuangan daerah di Kabupaten Kutai Kartanegara masih dihadapkan pada permasalahan pokok, yang terdiri dari masalah sumber daya manusia, masalah peraturan perundang-undangan, dan masalah infrastruktur. 1). Masalah sumber daya manusia (SDM); masih lemahnya sumber daya manusia yang terlibat dalam proses pengelolaan keuangan daerah dalam memahami peraturan-peraturan yang berkaitan dengan keuangan daerah, sehingga sering kali apa dan bagaimana yang telah dilakukan ternyata dinilai salah oleh pihak Inspektorat atau Badan Pemeriksa Keuangan (BPK). 2). Masalah Peraturan Perundang-undangan; Berbagai peraturan yang berkaitan dengan pengelolaan keuangan daerah masih mempunyai potensi multi penafsiran sehingga menimbulkan banyak persepsi mengenai tata laksana keuangan daerah. 3). Masalah Infrastruktur; penerapan Simda memerlukan akses internet yang baik di seluruh wilayah SKPD berada, karena system Simda yang online mengharuskan seluruh proses keuangan daerah dilaksanakan secara online, untuk itu fasilitas untuk mendukung proses keuangan secara online tersebut harus tersedia dengan baik. Perlu diketahui bahwa sampai saat ini baru beberapa wilayab SKPD yang mampu mengakses internet.

Tujuan Penelitian kajian ini adalah untuk mengetahui: 1). Implementasi Simda terhadap pengelolaan keuangan daerah di Kabupaten Kutai Kartanegara; 2). Kesiapan sumber daya manusia yang bertugas mengelola keuangan daerah serta mengetahui permasalahan yang dihadapi; 3). Dukungan dan fungsi 
Infrastruktur terhadap implementasi Simda di Kabupaten Kutai Kartanegara. Sedangkan Ruang lingkup kajian ini meliputi seluruh SKPD di kabupaten Kutai Kartanegara sebagai rangkaian system pengelolaan keuangan daerah. SKPD yang dimaksudkan bukan hanya yang dianggap dengan standar ruang lingkup pekerjaan yang luas dan kompleks, tetapi termasuk SKPD dengan ruang lingkup pekerjaan yang relative kecil dan sederhana seperti halnya di Kelurahan dan Desa.

Secara teoritis pengertian Simda dalam suatu pemahaman yang sederhana dapat didefinisikan sebagai satu sistem berbasis komputer yang menyediakan informasi bagi beberapa pemakai dengan kebutuhan yang serupa. Para pemakai biasanya tergabung dalam suatu entitas organisasi formal, seperti Departemen atau Lembaga suatu Instansi Pemerintahan yang dapat dijabarkan menjadi Direktorat, Bidang, Bagian sampai pada unit terkecil dibawahnya. Informasi menjelaskan mengenai organisasi atau salah satu sistem utamanya mengenai apa yang telah terjadi di masa lalu, apa yang sedang terjadi sekarang dan apa yang mungkin akan terjadi dimasa yang akan datang tentang organisasi tersebut.

Sistem informasi memuat berbagai informasi penting mengenai orang, tempat, dan segala sesuatu yang ada di dalam atau di lingkungan sekitar organisasi. Informasi sendiri mengandung suatu arti yaitu data yang telah diolah ke dalam suatu bentuk yang lebih memiliki arti dan dapat digunakan untuk pengambilan keputusan. Data sendiri merupakan faktafakta yang mewakili suatu keadaan, kondisi, atau peristiwa yang terjadi atau ada di dalam atau di lingkungan fisik organisasi. Data tidak dapat langsung digunakan untuk pengambilan keputusan, melainkan harus diolah lebih dahulu agar dapat dipahami, lalu dimanfaatkan dalam pengambilan keputusan.

Informasi harus dikelola dengan baik dan memadai agar memberikan manfaat yang maksimal. Penerapan sistem informasi di dalam suatu organisasi dimaksudkan untuk memberikan dukungan informasi yang dibutuhkan, khususnya oleh para pengguna informasi dari berbagai tingkatan manajemen. Sistem informasi yang digunakan oleh para pengguna dari berbagai tingkatan manajemen ini biasa disebut sebagai: Sistem Informasi Manajemen.

Sistem informasi mengandung tiga aktivitas dasar di dalamnya, yaitu: aktivitas masukan (input), pemrosesan (processing), dan keluaran (output). Tiga aktivitas dasar ini menghasilkan informasi yang dibutuhkan organisasi untuk pengambilan keputusan, pengendalian operasi, analisis permasalahan, dan menciptakan produk atau jasa baru. Masukan berperan di dalam pengumpulan bahan mentah ( raw data), baik yang diperoleh dari dalam maupun dari lingkungan sekitar organisasi. Pemrosesan berperan untuk mengkonversi bahan mentah menjadi bentuk yang lebih memiliki arti. Sedangkan, keluaran dimaksudkan untuk men-transfer informasi yang diproses kepada pihakpihak atau aktivitasaktivitas yang akan menggunakan. Sistem informasi juga membutuhkan umpan balik (feedback), yaitu untuk dasar evaluasi dan perbaikan di tahap input berikutnya.

Dewasa ini, sistem informasi yang digunakan lebih berfokus pada sistem informasi berbasis komputer (computer-based information system). Harapan yang ingin diperoleh di sini adalah bahwa dengan penggunaan teknologi informasi atau sistem informasi berbasis komputer, informasi yang dihasilkan dapat lebih akurat, berkualitas, dan tepat waktu, sehingga pengambilan keputusan dapat lebih efektif dan efisien.

Perkembangan konsep ini masih belum mulus dan banyak organisasi mengalami kegagalan dalam aplikasinya karena adanya beberapa hambatan, misalnya: a). kekurangpahaman para pemakai tentang computer; b). kekurangpahaman para spesialis bidang informasi tentang bisnis dan peran manajemen; c). relatif mahalnya harga perangkat computer; serta d). terlalu berambisinya para pengguna yang terlalu yakin dapat membangun sistem informasi secara lengkap sehingga dapat mendukung semua lapisan manajer.

Konsep SIM terus berkembang, Morton, Gorry, dan Keen dari Massachussets Institute of Technology (MIT) mengenalkan konsep baru yang diberi nama Sistem Pendukung Keputusan (Decision Support Systems - DSS). DSS adalah sistem yang menghasilkan informasi yang ditujukan pada masalah tertentu yang harus dipecahkan atau keputusan yang harus dibuat oleh manajer. Perkembangan yang lain adalah munculnya aplikasi lain, yaitu Otomatisasi Kantor (office automation - OA), yang memberikan fasilitas untuk meningkatkan komunikasi dan produktivitas para manajer dan staf kantor melalui penggunaan peralatan elektronik.

Belakangan timbul konsep baru yang dikenal dengan nama Artificial Intelligence (AI), sebuah konsep dengan ide bahwa komputer bisa diprogram untuk melakukan proses lojik menyerupai otak manusia. Suatu jenis dari AI yang banyak mendapat perhatian adalah Expert Systems (ES), yaitu suatu aplikasi yang mempunyai fungsi sebagai spesialis dalam area tertentu.

Semua konsep di atas, baik PDE, SM, OA, DSS, EIS, maupun AI merupakan aplikasi pemrosesan informasi dengan menggunakan komputer dan bertujuan menyediakan informasi untuk pemecahan masalah dan pengambilan keputusan.

Semakin meningkat saling ketergantungan antara rencana strategis instansi, peraturan dan prosedur disatu sisi dengan sistem informasi (software, hardware, database, dan telekomunikasi) disisi yang lainnya. Perubahan di satu komponen akan mempengaruhi komponen lainnya. Hubungan ini menjadi sangat kritikal manakala manajemen ingin membuat rencana ke depan. 
Aktivitas apa yang akan dilakukan lima tahun ke depan biasanya juga sangat tergantung kepada sistem apa yang tersedia untuk dapat melaksanakannya. Sebagai contoh, peningkatan produktivitas kerja para pegawai sangat tergantung pada jenis dan kualitas dari sistem informasi organisasi.

Jaringan yang terluas dan terbesar yang digunakan adalah internet. Hampir setiap orang di seluruh dunia ini, baik yang bekerja di dunia sains, pendidikan, pemerintah, maupun kalangan pebisnis menggunakan jaringan internet untuk bertukar informasi atau melakukan transaksi bisnis dengan orang atau organisasi lain di seluruh dunia. Internet menciptakan platform teknologi baru yang universal. Teknologi internet ini mampu mempertajam cara bagaimana sistem informasi digunakan dalam bisnis dalam kehidupan sehari-hari. Berbagai manfaat yang dapat diperoleh dengan penggunaan internet, di antaranya adalah untuk; Komunikasi dan kolaborasi, Akses data dan informasi, Partisipasi dalam diskusi, Supply informasi, Hobi atau bersenang-senang (entertainment), dan Pertukaran transaksi bisnis.

Pertumbuhan yang pesat di teknologi komputer dan jaringan, termasuk teknologi internet telah mengubah struktur organisasi yang memungkinkan secara instan informasi didistribusi di dalam dan di luar organisasi. Kemampuan ini dapat digunakan untuk mendesain ulang dan mempertajam organisasi, mentransfer struktur organisasi, ruang lingkup organisasi, melaporkan dan mengendalikan mekanisme, praktik-praktik kerja, arus kerja, serta produk dan jasa. Pada akhirnya, proses bisnis yang dilakukan secara elektronis membawa organisasi lebih dikelola secara digital, yang membawa dampak pada hal-hal sebagai berikut: (a). Organisasi semakin ramping; Organisasi yang gemuk dan birokratis lebih sulit untuk mengikuti perubahan yang pesat dewasa ini, kurang efisien, dan tidak dapat kompetitif. Oleh karenanya, banyak model organisasi ini sekarang dirampingkan, termasuk jumlah pegawainya dan tingkatan hirarkis manajemennya. (b). Pemisahan pekerjaan dari lokasi; Teknologi komunikasi telah mengeliminasi jarak sebagai satu faktor yang harus dipertimbangkan dalam pekerjaan.

Sistem Informasi dalam Pelaporan Keuangan Pemerintah di Indonesia, banyak diatur dalam Peraturan Perundangan seperti dalam PP No. 8 tahun 2006 tentang pelaporan keuangan dan kinerja institusi pemerintahan, yang secara detail diatur dalam Peraturan Pemerintah No. 24 tahun 2005 tentang Standar Akuntansi Keuangan Pemerintahan. Di samping itu, Peraturan Menteri Dalam Negeri No. 13 tahun 2006 tentang Pedoman Pengelolaan Keuangan Daerah yang telah diperbaharui dengan Permendagri No 59 tahun 2007 ikut memberikan pedoman bagi praktek akuntansi pengelolaan keuangan ditingkat daerah.
Catatan atas laporan keuangan pemerintah, sebagai komponen dalam laporan keuangan pokok dimaksudkan agar laporan keuangan dapat difahami oleh pembaca secara luas, tidak terbatas hanya pembaca tertentu ataupun manajemen entitas pelaporan. Oleh karena itu laporan keuangan mungkin mengandung informasi yang dapat mempunyai potensi kesalahfahaman di antara pembaca (multi tafsir).

1. Menurut Penelitian-penelitian sebelumnya.

Moonitz menyatakan disclosure sebagai postulat imperative. Selain itu dia mengungkapkan "That which is necessary to make them (accounting reports) not misleading)". Disclosure merupakan informasi keuangan yang relevan baik itu yang masuk dalam bagian utama laporan keuangan atau di luarnya, termasuk metode-metode yang digunakan dalam laporan keuangan di mana terlebih dahulu dari satu pilihan, termasuk itu metode yang inovatif diluar konvensional. (Wolk, Tearney, and Dodd, 2000).

Adapun Peraturan yang menyangkut Pengelolaan keuangan:

a. PP No. 8 tahun 2006 tentang pelaporan keuangan dan kinerja Institusi Pemerintahan

b. PP No. 24 tahun 2005 tentang Standar Akuntansi Keuangan Pemerintahan

c. Peraturan Menteri Dalam Negeri No. 13 tahun 2006 tentang pedoman pengelolaan keuangan Pemerintah Daerah

d. Peraturan Menteri Dalam Negeri No. 59 tahun 2007 tentang pedoman pengelolaan keuangan Pemerintah Daerah;

e. Peraturan Daerah No. 2 tahun 2005 tentang pokokpokok keuangan daerah;

f. Peraturan Daerah No. 18 tahun 2004;

g. Peraturan Daerah No. 16 tahun 2006;

h. Peraturan Daerah Kabupaten Kutai Kartanegara No. 11 tahun 2008;

i. Peraturan Daerah Kabupaten Kutai Kartanegara No. 12 tahun 2008;

j. Peraturan Daerah Kabupaten Kutai Kartanegara No. 15 tahun 2008;

k. Peraturan Daerah Kabupaten Kutai Kartanegara No. 16 tahun 2008;

1. Peraturan Bupati No. 1 tahun 2012 tentang pengelolaan keuangan daerah.

\section{METODE PENELITIAN}

Penelitian ini bersifat survey dengan pendekatan penelitian bersifat deskriptif, evaluative. Penelitian deskriptif dimaksudkan untuk mengukur secara cermat terhadap fenomena permasalahan pengelolaan keuangan yang didasarkan pada sejauh mana implementasi Simda. Sedangkan menurut Nazir (1999), penelitian deskriptif adalah studi untuk menemukan fakta dengan interpretasi yang tepat, sedangkan studi analitis, ditujukan untuk 
menguji hipotesa-hipotesa dan mengadakan interpretasi yang lebih dalam tentang hubungan-hubungan. Data pendukung (data skunder) adalah terkait dengan data series terkait pelaksanaan Simda di kabupaten Kutai Kartanegara pada tahun 2008 atau 2009 sejak diberlakukannya System Informasi Manajemen Daerah.

Lokasi Penelitian berada di wilayah Kutai Kartanegara dengan populasi sebanyak 18 kecamatan. Sementara itu, sampel penelitian 15 kecamatan yang ditetapkan secara purposive sampling, yang terdiri dari: Kecamatan Tenggarong Seberang, Kecamatan Loa Kulu, Kecamatan Loa Janan, Kecamatan Sebulu, Kecamatan Kota Bangun, Kecamatan Sanga-sanga, Kecamatan Aggana, Kecamatan Samboja, Kecamatan Marang Kayu, Kecamatan Muara Badak, Kecamatan Muara Jawa, Kecamatan Muara Kaman, Kecamatan Muara Muntai, Kecamatan Muara Wis, dan Kecamatan Kenohan.

Masing-masing kecamatan diwakili oleh person yang bersinggungan langsung dengan implementasi Simda, yang terdiri dari pengguna, operator dan administrasi Simda. Metode pengumpulan data dengan cara menyebarkan kuesioner kepada responden yang telah ditentukan jumlahnya. Responden dipilih berdasarkan stratified sampling random. Dimana responden penelitian adalah seluruh Kasubbag Keuangan dan Bendahara pengeluaran di SKPD Pemkab Kutai Kartanegara dengan rincian. Dengan demikian total sampel penelitian adalah sebanyak 152 responden.

Selain itu, penelitian ini juga melakukan interview dengan beberapa informan kunci (key informan) para implementator Simda. Penentuan informan kunci dilakukan secara purposive (sengaja), dengan memperhatikan aspek keterwakilan implementator Simda, yang terdiri dari administraror, operator, dan pejabat pengelola keuangan di Kabupaten Kutai Kartanegara.

Analisa data yang digunakan adalah analisis kualitatif dan kuantitatif. Analisa kualitatif adalah dengan menganalisa kecenderungan tingkat presentasi terkait fenomena yang terjadi. Hasil yang diperkirakan adalah dapat mengetahui sejauh mana tingkat keberhasilan program Simda dalam proses manajemen pengelolaan keuangan daerah Kutai Kartanegara.

\section{HASIL DAN PEMBAHASAN}

Hasil penelitian mengacu kepada hasil jawaban kuesioner yang disebar kepada responden untuk mengungkapkan implementasi Simda dalam pengelolaan keuangan di Kabupaten Kutai Kartanegera. Implementasi Simda yang terungkap dari jawaban responden tersebut, akan dikelompokkan ke dalam tiga hasil pokok yaitu: 1) Implementasi Simda, 2) Kesiapan Sumberdaya Manusia, dan 3) Dukungan dan Fungsi Infrastruktur.
Implementasi Simda dilakukan pada setiap fungsi keuangan pemerintah seperti penganggaran, penatausahaan dan akuntansi serta pelaporan. Evaluasi terhadap implementasi Simda dilakukan dengan membandingkan waktu standard dan waktu faktual setiap proses penyelesaian satu produk Simda. Waktu standard adalah waktu penyelesaian output standard berdasarkan peraturan yang telah digariskan pemerintah, yaitu Permendagri Nomor 13 Tahun 2006. Sedangkan waktu faktual adalah waktu penyelesaian output rata-rata yang riil dihasilkan responden dalam satu SKPD.

Perbandingan waktu faktual dan waktu standar akan menentukan tingkat implementasi Simda, dengan asumsi bahwa; a) jika waktu standar lebih lama dibanding waktu faktual, maka Simda telah dapat diimplementasikan dengan baik. b) Jika waktu faktual lebih lama dibanding waktu standard, maka Simda belum dapat diimplementasikan dengan baik.

Implementasi Simda yang pertama adalah impelementasi dari aspek Penganggaran, yang meliputi proses pembuatan Rencana Kerja Anggaran (RKA), Dokumen Pelaksanaan Anggaran (DPA), dan Surat Penyediaan Dana (SPD). Tabel 1. berikut ini menggambarkan implementasi Simda dari Aspek Penganggaran.

Tabel 1. Implementasi Simda pada Aspek Penganggaran

\begin{tabular}{lcc}
\hline \multicolumn{1}{c}{ Output } & $\begin{array}{c}\text { Waktu } \\
\text { Standard } \\
\text { (Hari) }\end{array}$ & $\begin{array}{c}\text { Waktu } \\
\text { Faktual } \\
\text { (Hari) }\end{array}$ \\
\hline $\begin{array}{l}\text { Rencana Kerja } \\
\text { Anggaran (RKA) }\end{array}$ & 6 & 2,97 \\
$\begin{array}{l}\text { Dokumen Pelaksanaan } \\
\text { Anggaran (DPA) } \\
\text { Surat Penyediaan Dana } \\
\text { (SPD) }\end{array}$ & 6 & 2,39 \\
\hline
\end{tabular}

Sumber: Permendagri Nomor 13 Tahun 2006 dan Hasil Pengolahan Data Primer, 2012

Tabel 1. memperlihatkan bahwa Implementasi Simda dari aspek penganggaran berada pada tingkat yang relatif tinggi. Proses pembuatan RKA dan DPA rata-rata tertimbang memerlukan waktu 2,97 dan 2,39 hari dari waktu standard 6 hari dalam Permendagri Nomor 13 Tahun 2006. Proses pembuatan SPD rata-rata tertimbang hanya memerlukan 3,45 hari dari waktu standard 7 hari dalam Permendagri Nomor 13 Tahun 2006. Dari ketiga proses dan jenis produk Simda dari aspek penganggaran, maka pembuatan DPA adalah yang paling tinggi tingkat implementasinya. Dengan demikian dapat diputuskan bahwa semua proses pembuatan produk Simda dari aspek penganggaran telah berada di bawah waktu standard yang ditetapkan oleh 
Permendagri Nomor 13 Tahun 2006, yaitu di bawah 6 dan 7 hari.

Implementasi Simda yang kedua adalah implementasi pada aspek penatausahaan, yang meliputi proses pembuatan Surat Perintah Pembayaran (SPP), Surat Perintah Membayar (SPM), Surat Perintah Penyediaan Dana (SP2D), dan Surat Tanda Setoran. Tabel 2. berikut ini perbandingan waktu tertimbang setiap proses pembuatan Simda dari aspek penatausahaan.

Tabel 2. Implementasi Simda pada Aspek Penatausahaan

\begin{tabular}{|c|c|c|}
\hline Output & $\begin{array}{l}\text { Waktu } \\
\text { Standard } \\
\text { (Hari) }\end{array}$ & $\begin{array}{c}\text { Waktu } \\
\text { Faktual } \\
\text { (Hari) }\end{array}$ \\
\hline $\begin{array}{l}\text { Surat Perintah } \\
\text { Pembayaran (SPP) }\end{array}$ & 2 & 1,31 \\
\hline $\begin{array}{l}\text { Surat Perintah } \\
\text { Membayar (SPM) }\end{array}$ & 2 & 1,46 \\
\hline $\begin{array}{l}\text { Surat Perintah } \\
\text { Penyediaan Dana } \\
\text { (SP2D) }\end{array}$ & 2 & 1,64 \\
\hline $\begin{array}{l}\text { Surat Tanda Setoran } \\
\text { (STS) }\end{array}$ & 2 & 1,57 \\
\hline
\end{tabular}

Sumber: Permendagri Nomor 13 Tahun 2006 dan Hasil Pengolahan Data Primer, 2012

Tabel 2. memberikan gambaran bahwa proses pembuatan Surat Perintah Pembayaran (SPP) adalah yang paling tinggi tingkat implementasinya, dengan waktu 1,31 hari. Setelah itu adalah proses pembuatan Surat Perintah Membayar (SPM) dengan waktu 1,46 hari. Proses pembuatan SP2D di sisi lain memerlukan waktu yang paling lama, yaitu 1,64 hari, dan kemudian diikuti proses pembuatan Surat Tanda Setoran (STS) dengan waktu 1,57 hari. Meski demikian semua proses pembuatan produk Simda dari aspek penatausahaan, telah berada di bawah waktu standard yang ditetapkan Permendagri Nomor 13 Tahun 2006, yaitu di bawah 2 hari $(<2$ hari).

Implementasi Simda pada aspek akuntansi dan pelaporan mencakup beberapa produk seperti jurnal, buku besar, buku pembantu, laporan realisasi kas, laporan arus kas, dan neraca. Tidak ada standard waktu yang ditetapkan Permendagri Nomor 13 Tahun 2006. Namun, produk Simda dari aspek akuntansi dan pelaporan ini digunakan oleh bagian keuangan Sekretariat Daerah untuk pembuatan Laporan Keuangan Pemerintah Daerah (LKPD).
Tabel .3 Implementasi Simda pada Aspek Akuntansi dan Pelaporan

\begin{tabular}{rlcc}
\hline & Output & $\begin{array}{c}\text { Waktu } \\
\text { Standard } \\
\text { (Hari) }\end{array}$ & $\begin{array}{c}\text { Waktu } \\
\text { Faktual } \\
\text { (Hari) }\end{array}$ \\
\hline SKPD & & & \\
1. & Jurnal & & 2,20 \\
2. & Buku Besar & & 2,11 \\
3. & Buku Pembantu & & 2,58 \\
4. & Laporan & Non & 8,13 \\
& Realisasi & Standard & \\
& Anggaran & & 6,27 \\
5. & Laporan Arus & \\
& Kas & 6,10 \\
6. & Neraca & & \\
\hline Pemda & \multicolumn{3}{c}{ 6 Bulan } \\
\multicolumn{4}{c}{ setelah TA } \\
Serakhir \\
Sumber: Permendagri Nomor 13 Tahun 2006 dan Hasil \\
Pengolahan Data Primer, 2012
\end{tabular}

Tabel di atas memberikan gambaran bahwa semua proses pembuatan produk Simda dari aspek akuntansi dan pelaporan, yang meliputi jurnal sampai dengan neraca memerlukan waktu di bawah 9 hari. Waktu tersingkat adalah 2,11 hari untuk pembuatan buku besar, sedangkan waktu terlama adalah 8,13 hari untuk pembuatan Laporan Realisasi Anggaran. Namun, semua produk akuntansi dan pelaporan ini, memerlukan waktu jauh di bawah standard pembuatan LKPD yang mencapai 6 bulan setelah tahun anggaran berakhir.

Jika mengacu pada hasil penelitian ini dapat dikatakan bahwa implementasi Simda di Kabupaten Kutai Kartanegara relatif telah cukup tinggi. Semua produk Simda dapat dilakukan di bawah rata-rata standard yang ditetapkan dalam Permendagri Nomor 13 Tahun 2006. Namun, produk Simda ini adalah produk parsial yang dihasilkan oleh Simda SKPD. Artinya, bukan produk lanjutan berupa LKPD yang dihasilkan oleh bagian keuangan sekretariat daerah. LKPD masih memerlukan proses lebih lanjut, berupa pengumpulan data dari seluruh SKPD termasuk sistem pertanggungan jawaban keuangan lainnya seperti pengelolaan aset dan pengelolaan keuangan non kas.

Selanjutnya sumber daya manusia merupakan bagian terpenting dalam implementasi Simda. Kesiapan sumber daya manusia untuk mengimplementasikan Simda di Kabupaten Kutai Kartanegara mencakup beberapa hal, yaitu; 1) Karaktersitik responden pengelola Simda, 2) Pengetahuan dan Skill sumber daya manusia dalam pengoperasian Simda.

\section{Karakterisitik Responden Pengelola Simda}

Pengelola Simda yang terdiri atas administrator, operator dan pengguna yang menjadi responden 
penelitian ini mayoritas berstatus PNS, dengan komposisi 90,8\% berbanding 9,2\% Non PNS, seperti terlihat pada Tabel 4.4. Untuk kelompok PNS terdapat 10 orang administrator, 25 orang operator dan 73 orang pengguna Simda. Sedangkan untuk kelompok non PNS terdapat 4 orang operator dan 7 orang pengguna Simda.

Kesiapan sumber daya manusia dalam pengoperasian Simda, salah satunya adalah pengalaman pengelola. Kesiapan SDM memberikan gambaran bahwa mayoritas pengelola Simda di Kabupaten Kutai Kartanegara memiliki pengalaman 2 tahun, yaitu 47,9\%. Data ini mengindikasikan bahwa pengelola Simda relatif memiliki pengalaman yang cukup, bahkan terdapat beberapa pengelola yang memiliki pengalaman di atas 2 tahun, sebanyak 10,9\%. Pengalaman belum lengkap jika tidak disertai dengan pendidikan untuk melihat gambaran kesiapan pengelola dalam mengopersikan Simda. Tabel 4.6 berikut ini akan memberikan gambaran hal tersebut.

Hasil analisis memberikan gambaran bahwa pendidikan pengelola Simda relatif cukup tinggi, mengingat mayoritas pengelola adalah sarjana S1 sebanyak 45,4\% dan S2 sebanyak 8,4\%, yang jika dijumlah adalah sebesar 53,8\%. Pengelola yang berpendidikan SMA di sisi lain berjumlah lebih rendah, yaitu hanya $46,2 \%$. Artinya dari aspek pendidikan, para pengelola Simda dapat dikatakan siap dalam mengimplementasikan Simda.

Pengetahuan tentang Simda dibagi menjadi beberapa aspek, yaitu: aspek penganggaran, penatausahaan, dan aspek akuntansi serta pelaporan. Jawaban kuesioner yang disediakan untuk ketiga aspek tersebut adalah; tidak tahu, kurang tahu, tahu, dan sangat tahu. Masing-masing aspek memiliki beberapa komponen yang harus diketahui oleh responden untuk dapat mengimplementasikan Simda dengan optimal. Semakin lengkap responden mengetahui komponen pada tiga aspek Simda ini, maka semakin berpengetahuan responden tersebut. Sebaliknya semakin tidak lengkap, maka pengetahuan responden cenderung semakin rendah.

Tabel 4. Pengetahuan Responden Pengelola operasianal Simda dari Aspek Penganggaran

\begin{tabular}{lccccc}
\hline \multirow{2}{*}{$\begin{array}{l}\text { Pengetahuan } \\
\text { Responden }\end{array}$} & \multicolumn{4}{c}{ Peran dalam Simda } & \multirow{2}{*}{ Total } \\
\cline { 2 - 5 } & Administrator Operator Pengguna & \\
\hline Tidak Tahu & $\mathrm{F}$ & 0 & 0 & 3 & 3 \\
\cline { 2 - 6 } & $\%$ & $0 \%$ & $.0 \%$ & $3.8 \%$ & $2.5 \%$ \\
\cline { 2 - 5 } $\begin{array}{l}\text { Kurang } \\
\text { Tahu }\end{array}$ & $\mathrm{F}$ & 4 & 11 & 29 & 44 \\
\cline { 2 - 5 } Tahu & $\%$ & $40.0 \%$ & $37.9 \%$ & $36.2 \%$ & $37.0 \%$ \\
\cline { 2 - 5 } & $\%$ & 1 & 12 & 29 & 42 \\
\hline
\end{tabular}

\begin{tabular}{lccccc}
\hline Sangat & $\mathrm{F}$ & 5 & 6 & 19 & 30 \\
\cline { 2 - 6 } Tahu & $\%$ & $50.0 \%$ & $20.7 \%$ & $23.8 \%$ & $25.2 \%$ \\
\hline \multirow{2}{*}{ Jumlah } & $\mathrm{F}$ & 10 & 29 & 80 & 119 \\
\cline { 2 - 6 } & $\%$ & $100.0 \%$ & $100.0 \%$ & $100.0 \%$ & $100.0 \%$ \\
\hline
\end{tabular}

Sumber: Hasil Pengolahan Data Primer, 2012

Pengetahuan responden dari aspek peganggaran meliputi pengetahuan responden tentang Rencana Kerja Anggaran (RKA), Dokumen Pelaksanaan Anggaran (DPA), APBD beserta Perubahannya, dan Surat Penyediaan Dana (SPD). Semakin lengkap responden mengetahui komponen pada aspek penganggaran ini, maka semakin berpengetahuan responden tersebut.

Tabel 4. menggambarkan bahwa pengetahuan pengelola dalam mengimplementasikan Simda dari aspek pengganggaran relatif cukup. Keputusan ini diambil mengingat mayoritas responden mengetahui dengan cukup lengkap komponen-komponen dalam aspek penganggaran yang dapat dilakukan dengan Simda, yaitu: Rencana Kerja Anggaran (RKA), Dokumen Pelaksanaan Anggaran (DPA), APBD beserta Perubahannya, dan Surat Penyediaan Dana (SPD). Sebaran responden yang tahu dan sangat tahu implementasi Simda dari aspek penganggaran adalah $60,5 \%$. Sedangkan responden yang kurang tahu dan tidak tahu hanya sebanyak 39,5\%

Selain pengetahuan dari aspek penganggaran, pengetahuan tentang implementasi Simda juga dapat dilihat dari aspek penatausahaan. Implementasi Simda dari aspek penatausahaan terdiri dari Surat Permintaan Pembayaran (SPP), Surat Perintah Pencairan Dana (SP2D), Surat Tanda Setoran (STS), dan Register serta Formulir Pengendalian Lainnya. Semakin lengkap responden mengetahui komponen pada aspek penganggaran ini, maka semakin berpengetahuan responden tersebut. Sebaliknya, semakin banyak komponen yang tak diketahui responden dalam penatausahaan, maka semakin kurang pengetahuan responden tersebut.

Hasil analisis akan menggambarkan pengetahuan pengelola tentang implementasi Simda dari aspek penatausahaan berdasarkan peran responden dalam Simda, yaitu administrator, operator dan pengguna Simda. Juga mengambarkan bahwa pengetahuan pengelola dalam implementasi Simda dari aspek penatausahaan relatif kurang, mengingat mayoritas responden tidak dan kurang mengetahui dengan cukup lengkap komponen-komponen dalam aspek penatausahaan yang dapat dilakukan dengan Simda. Sebaran responden yang tidak tahu dan kurang tahu implementasi Simda dari aspek penatausahaan adalah $51,7 \%$, berbanding $48,3 \%$ responden yang tahu dan sangat tahu.

Aspek ketiga dari pengetahuan tentang implementasi Simda adalah akuntansi dan pelaporan. 
Komponen dalam aspek akuntansi dan pelaporan adalah Junal, Buku Besar, dan Buku Pembantu, Buku Kas Pembantu, Laporan Realisasi Anggaran, Laporan Arus Kas, dan Neraca. Selanjutnya Hasil analisis tentang pengetahuan pengelola tentang implementasi Simda dari aspek akuntansi dan pelaporan mengambarkan bahwa pengetahuan pengelola dalam implementasi Simda dari aspek akuntansi dan pelaporan adalah sangat baik, mengingat mayoritas responden tahu dan sangat tahu dengan cukup lengkap komponen-komponen dalam aspek akuntansi dan pelaporan yang dapat dilakukan dengan Simda. Sebaran responden yang sangat tahu dan tahu implementasi Simda dari aspek akuntansi dan pelaporan adalah $70,6 \%$, berbanding $29,4 \%$ responden yang kurang tahu dan tidak tahu.

Berdasarkan hasil tabulasi jawaban responden tentang pengetahuan dari ketiga aspek implementasi Simda, dapat diketahui bahwa pengetahuan pada dua aspek relatif baik dan sangat baik, yaitu aspek penganggaran dan akuntansi serta pelaporan. Sementara aspek penatausahaan relatif tidak sebaik pengetahuan responden pada dua aspek lainnya.

Skill pengoperasian Simda meliputi pelatihan dan pasca pengoperasian. Pelatihan dilakukan oleh penyedia Layanan Simda dalam hal ini adalah BPKP. Hal ini diakui oleh para responden sebagaimana pada Tabel 5.

Tabel 5. memberikan gambaran bahwa mayoritas responden telah memperoleh pelatihan dari penyedia layanan Simda. Tercatat $88,2 \%$ telah memperoleh pelatihan. Selebihnya, terdapat $11,8 \%$ yang belum mendapatkan pelatihan. Angka 11,8\% responden yang belum mendapatkan pelatihan, mendapatkan pengetahuan dan skill pengimplementasian Simda dari rekan kerja yang telah mendapatkan pelatihan. Pelatihan, idealnya dapat meningkatkan pengetahuan dan keterampilan pengoperasian Simda.

Skill pengelola Simda diperlukan saat muncul berbagai masalah teknis dalam pengoperasian software ini. Berdasarkan rekapitulasi, meski tidak terlalu sering, namun masalah teknis bisa saja muncul. Hasil analisis memberikan gambaran bahwa mayoritas pengelola Simda pernah mengalami masalah teknis, yaitu 97,4\%. Angka 97,4\% mencerminkan bahwa software ini relatif cukup baik, apalagi hanya $7,6 \%$ yang menyebutkan bahwa sering terjadi masalah teknis. Laiknya sebuah software, pasti mengandung kelemahan dan tidak

Tabel 5. Partisipasi Responden dalam Pelatihan Selama Pengoperasian Simda

\begin{tabular}{|c|c|c|c|c|c|}
\hline \multirow{2}{*}{\multicolumn{2}{|c|}{$\begin{array}{l}\text { Partisipasi dalam } \\
\text { Pelatihan }\end{array}$}} & \multicolumn{3}{|c|}{ Peran dalam Simda } & \multirow{3}{*}{$\begin{array}{c}\text { Total } \\
107\end{array}$} \\
\hline & & \multirow{2}{*}{$\begin{array}{c}\text { Administrator } \\
9\end{array}$} & \multirow{2}{*}{$\frac{\text { Operator }}{26}$} & \multirow{2}{*}{$\begin{array}{c}\text { Pengguna } \\
72\end{array}$} & \\
\hline Ya & $\mathrm{F}$ & & & & \\
\hline $\mathrm{rd}$ & $\%$ & $90.00 \%$ & $89.66 \%$ & $90.00 \%$ & $89.92 \%$ \\
\hline \multirow{2}{*}{ Tidak } & $\mathrm{F}$ & 1 & 3 & 8 & 12 \\
\hline & $\%$ & $10.00 \%$ & $10.34 \%$ & $10.00 \%$ & $10.08 \%$ \\
\hline \multirow{2}{*}{ Jumlah } & $\mathrm{F}$ & 10 & 29 & 80 & 119 \\
\hline & $\%$ & $100.00 \%$ & $100.00 \%$ & $100.00 \%$ & $100.00 \%$ \\
\hline
\end{tabular}

Sumber: Hasil Pengolahan Data Primer, 2012

manfaat yang diperoleh dari pelatihan untuk peningkatan skill pengelola sehingga diperoleh sumber daya manusia yang siap mengoperasikan Simda. Sementara pengoperasian Simda sendiri bukan hanya mencakup aspek pengimplementasiannya yang berupa penganggaran, penatausahaan, dan akuntansi serta pelaporan saja, tetapi juga mencakup penanganan dini jika implementasi Simda bermasalah.

Pelatihan dilakukan bukan hanya saat awal dimulainya penggunaan Simda, tetapi juga dilakukan mungkin bisa sempurna. Angka masalah teknis yang hanya $7,6 \%$ adalah angka yang relatif kecil untuk sebuah software.

Masalah teknis yang muncul, meski kecil namun tetap memerlukan antisipasi. Antisipasi pertama adalah mengetahui jenis masalah teknis yang paling sering muncul. Data berikut ini adalah jenis masalah teknis yang muncul saat pengoperasian Simda. 
Tabel 6. Jangka Waktu Pembuatan Laporan dalam Implementasi Simda

\begin{tabular}{|c|c|c|c|c|c|}
\hline \multirow{2}{*}{ Jangka Waktu } & & \multicolumn{3}{|c|}{ Peran dalam Simda } & \multirow{2}{*}{ Total } \\
\hline & & Administrator & Operator & Pengguna & \\
\hline \multirow{2}{*}{ Harian } & $\mathrm{F}$ & 7 & 26 & 71 & 104 \\
\hline & $\%$ & $70.0 \%$ & $89.7 \%$ & $88.8 \%$ & $87.4 \%$ \\
\hline \multirow{2}{*}{ Mingguan } & $\mathrm{F}$ & 3 & 2 & 6 & 11 \\
\hline & $\%$ & $30.0 \%$ & $6.9 \%$ & $7.5 \%$ & $9.2 \%$ \\
\hline \multirow{2}{*}{ Bulanan } & $\mathrm{F}$ & 0 & 1 & 3 & 4 \\
\hline & $\%$ & $.0 \%$ & $3.4 \%$ & $3.8 \%$ & $3.4 \%$ \\
\hline \multirow{2}{*}{ Jumlah } & $\mathrm{F}$ & 10 & 29 & 80 & 119 \\
\hline & $\%$ & $100.0 \%$ & $100.0 \%$ & $100.0 \%$ & $100.0 \%$ \\
\hline
\end{tabular}

Sumber: Hasil Pengolahan Data Primer, 2012

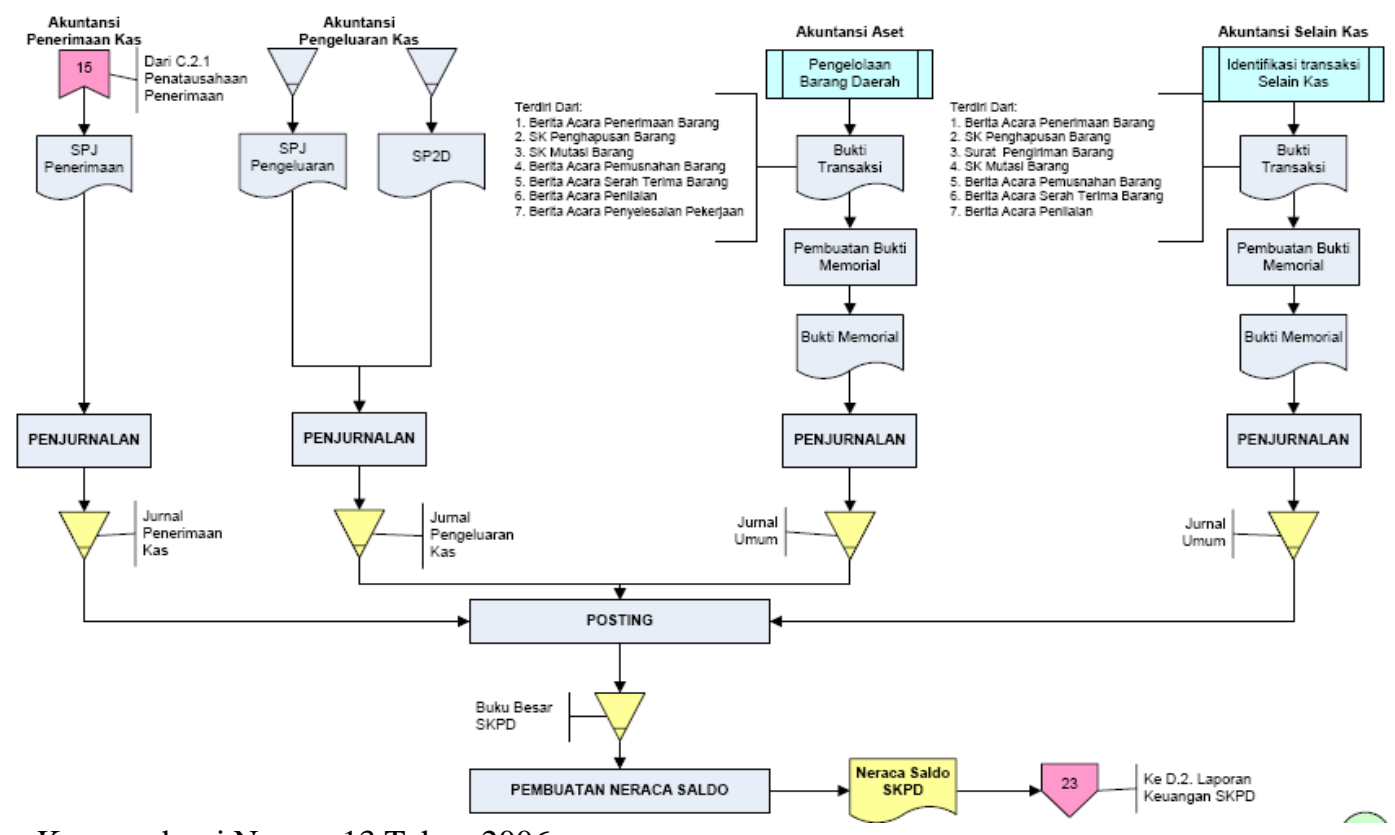

Sumber: Kepmendagri Nomor 13 Tahun 2006.

Gambar 1. Proses Akuntansi dan Pelaporan SKPD

Jenis masalah teknis yang paling sering muncul ternyata adalah virus $(70,6 \%)$, selanjutnya tidak tahu $(17,6 \%)$, dan Operating System (OS) dengan 6,7\%. Software Simda sendiri malah hanya memunculkan masalah teknis yang paling kecil, yaitu 5\%. Artinya software ini sebenarnya cukup baik dan ideal untuk implementasi Simda.

Terkait dengan skill atau keterampilan pengelola Simda, maka cara mengatasi jika terjadi masalah teknis adalah salah satu faktor yang dapat menunjukkan skill pengelola. Jika skill pengelola cukup baik, maka pengelola bisa saja memperbaiki sendiri atau bertanya dengan teman atau rekan yang pernah mengalami masalah teknis sejenis. Sebaliknya, jika skill kurang atau tidak, pengelola Simda cenderung akan membiarkan atau bahkan tidak tahu apa yang harus dilakukan jika terdapat masalah teknis saat Simda dioperasikan. Data berikut ini akan menggambarkan skill pengelola, jika mengalami masalah teknis dalam mengoperasikan Simda.

Mayoritas pengelola memanggil teknisi, yaitu $38,7 \%$ saat terjadi masalah teknis dalam pengeoperasian Simda. Bahkan, terdapat $32,8 \%$ pengelola yang membiarkan saja jika terjadi masalah. Hanya sedikit di antara responden yang mencoba memperbaiki sendiri atau bertanya kepada teman, masing-masing 5\% dan $3,4 \%$. Data ini menunjukkan bahwa skill dan inisitaip pengelola relatif masih lemah.

Hasil analisis memberikan gambaran bahwa mayoritas pengelola Simda memiliki masalah nonteknis 
dalam bentuk kurangnya pengetahuan $(26,1 \%)$, dan kurangnya komunikasi dengan pengguna dan sesama pengelola Simda $(25,2 \%)$. Data ini mengisyaratkan bahwa masalah nonteknis bisa muncul yang disebabkan oleh faktor internal pengelola. Artinya, meski masalah nonteknis relatif kecil, namun perlu diantisipasi dengan memperbaiki kinerja internal dari dalam pengelola sendiri.

Mengacu pada kesiapan Sumberdaya manusia pengelola Simda, dapat dikatakan cukup baik. Hal ini terlihat dari rata-rata pengalaman pengelola yang cukup tinggi ( $>2$ tahun) dan pendidikan yang cukup tinggi (rata-rata S1). Rata-rata responden juga memiliki pengatahuan yang cukup tentang Simda, terutama untuk aspek akuntansi dan pelaporan. Pengetahuan responden dari aspek penganggaran dan penatausahaan, meski sudah cukup baik, namun masih perlu ditingkatkan. Skill di SKPD. Bagan berikut akan menggambarkan proses tersebut.

Berdasarkan Gambar 1 dapat diketahui bahwa terdapat empat bagian dalam setiap proses akuntansi dan pelaporan, yaitu akuntansi penerimaan dan pengeluaran kas, akuntansi aset, dan akuntansi selain kas. Dari ke empat bagian akuntansi tersebut, akuntansi aset adalah bagian yang paling rumit mengingat proses pekerjaannya bersifat kontinyu. Akuntansi aset inilah letak kelemahan Kabupaten Kutai Kartanegara. Perolehan predikat disclaimer lebih banyak disebabkan karena akuntansi aset, dipandang oleh BPK masih bermasalah.

Pengamatan peneliti, akuntansi aset memerlukan sumber daya manusia yang memiliki spesifikasi khusus dari bidang akuntansi. Selain itu juga dilatih secara khusus pada bidang akuntansi pemerintahan.

Tabel 7. Jenis Jaringan yang Digunakan dalam Simda

\begin{tabular}{|c|c|c|c|c|c|}
\hline \multirow{2}{*}{ Jangka Waktu } & & \multicolumn{3}{|c|}{ Peran dalam Simda } & \multirow{2}{*}{ Total } \\
\hline & & Administrator & Operator & Pengguna & \\
\hline \multirow{2}{*}{ WAN } & $\mathrm{F}$ & 6 & 11 & 34 & 51 \\
\hline & $\%$ & $60.0 \%$ & $37.9 \%$ & $42.5 \%$ & $42.9 \%$ \\
\hline \multirow{2}{*}{ FO } & $\mathrm{F}$ & 2 & 4 & 19 & 25 \\
\hline & $\%$ & $20.0 \%$ & $13.8 \%$ & $23.8 \%$ & $21.0 \%$ \\
\hline \multirow{2}{*}{ Lainnya } & $\mathrm{F}$ & 2 & 14 & 27 & 43 \\
\hline & $\%$ & $20.0 \%$ & $48.3 \%$ & $33.8 \%$ & $36.1 \%$ \\
\hline \multirow{2}{*}{ Jumlah } & $\mathrm{F}$ & 10 & 29 & 80 & 119 \\
\hline & $\%$ & $100.0 \%$ & $100.0 \%$ & $100.0 \%$ & $100.0 \%$ \\
\hline
\end{tabular}

Sumber: Hasil Pengolahan Data Primer, 2012

Tabel 8. Frekuensi Penggunaan Fasiltas Teleconference Simda

\begin{tabular}{lccccc}
\hline \multirow{2}{*}{ Jangka Waktu } & \multicolumn{3}{c}{ Peran dalam Simda } & \multirow{2}{*}{ Total } \\
\cline { 2 - 5 } \multirow{2}{*}{ Sering } & Administrator & Operator & Pengguna & \\
\hline \multirow{2}{*}{ Pernah } & F & 10 & 25 & 75 & 110 \\
\cline { 2 - 5 } & $\%$ & $100.0 \%$ & $86.2 \%$ & $93.8 \%$ & $92.4 \%$ \\
\hline \multirow{2}{*}{ Jumlah } & F & 0 & 4 & 5 & 9 \\
\cline { 2 - 5 } & $\%$ & $.0 \%$ & $13.8 \%$ & $6.2 \%$ & $7.6 \%$ \\
\cline { 2 - 5 } & $\%$ & $100.0 \%$ & $100.0 \%$ & $100.0 \%$ & $100.0 \%$ \\
\hline
\end{tabular}

Sumber: Hasil Pengolahan Data Primer, 2012

para pengelola juga perlu ditingkatkan mengingat sebagian besar responden kurang memiliki inisiatif untuk mencoba mengatasi masalah saat pengoperasian Simda sedang bermasalah.

Simda pada dasarnya akan mengefisiensikan dan mengefektifkan berbagai proses akuntansi dan pelaporan
Penempatan petugas yang khusus menangani akuntansi aset juga harus kontinyu, mengingat spesifikasi pekerjaan ini saling berhubungan setiap tahunnya. Minimal, mutasi hanya dapat dilakukan pada instansi yang berbeda, namun tetap pada tupoksi akuntansi aset. Hindari sedapat mungkin penempatan pegawai yang 
Tabel 9. Masalah Software Simda

\begin{tabular}{lcccccc}
\hline \multirow{2}{*}{ Jangka Waktu } & & \multicolumn{3}{c}{ Peran dalam Simda } & \multirow{2}{*}{ Total } \\
\cline { 2 - 6 } & & Administrator & Operator & Pengguna & \\
\hline Kesulitan Memproteksi Virus & $\mathrm{F}$ & 4 & 11 & 38 & 53 \\
\cline { 2 - 6 } & $\%$ & $40.0 \%$ & $37.9 \%$ & $47.5 \%$ & $44.5 \%$ \\
\hline Fitur Software Kurang Familiar & $\mathrm{F}$ & 4 & 4 & 22 & 30 \\
\cline { 2 - 6 } & $\%$ & $40.0 \%$ & $13.8 \%$ & $27.5 \%$ & $25.2 \%$ \\
\hline Tindak Menguasai Semua Aplikasi & $\mathrm{F}$ & 2 & 14 & 20 & 36 \\
\cline { 2 - 6 } & $\%$ & $20.0 \%$ & $48.3 \%$ & $25.0 \%$ & $30.3 \%$ \\
\hline \multicolumn{1}{c}{ Jumlah } & $\mathrm{F}$ & 10 & 29 & 80 & 119 \\
\cline { 2 - 6 } & $\%$ & $100.0 \%$ & $100.0 \%$ & $100.0 \%$ & $100.0 \%$ \\
\hline
\end{tabular}

Sumber: Hasil Pengolahan Data Primer, 2012

tidak sesuai keahlian atau berasal pada tupoksi yang tidak segaris dengan tupoksi asets.

Kesiapan daya dukung dan fungsi infrastuktur dalam implementasi Simda mencakup jenis jaringan, fasilitas teleconference, software, hardhare, rasa memiliki, upaya pengoptimalisasian Simda, dukungan finansial, pemeriksaan rutin, koordinasi dan evaluasi Simda, strategi perlindungan terhadap Simda.

Jenis jaringan yang digunakan oleh Kabupaten Kutai Kartanegara dalam Simda terdiri dari WAN, FO dan jenis jaringan lainnya. Berdasarkan data yang dihimpun penelitian ini, jenis jaringan yang paling banyak dipakai adalah WAN dengan 42,9\%, sementara jenis jaringan FO hanya digunakan oleh $21 \%$. Tabel berikut ini memberikan gambaran lengkap tentang jenis jaringan yang digunakan Simda di Kabupaten Kutai Kartanegara.

Simda yang digunakan di Kab. Kukar juga memberikan fasilitas teleconference. Pemanfaatan fasilitas ini sudah dilakukan oleh para pengguna Simda, bahkan dapat dikatakan sudah dapat dimanfaatkan secara maksimal. Tabel berikut ini akan memberikan gambaran penggunaan fasilitas teleconference oleh pengguna Simda.

Terkait dengan software Simda, terdapat beberapa hal yang menjadi masalah, yaitu kesulitan memproteksi virus, kurang familiar dengan software Simda, dan tidak menguasai semua aplikasi Simda. Tabel 9. memberikan gambaran bahwa masalah yang sering muncul saat menggunakan software adalah kesulitan memproteksi virus $(44,5 \%)$. Masalah lainnya adalah para responden tidak menguasai semua aplikasi yang ada dalam Simda sebanyak $30.3 \%$, dan responden tidak atau kurang familiar dengan semua fitur Simda sebanyak 25,5\%. Data pada Tabel 9 dibawah ini mengindikasikan bahwa masalah yang muncul saat pengoperasian Simda tidak sepenuhnya muncul dari kelemahan software Simda, namun dari eksternal berupa virus.

Implementasi Simda tidak terlepas dari kelengkapan hardware yang digunakan. Terdapat dua kelompok kelengkapan hardware yang digunakan, yaitu spesifikasi hardware dan spesifikasi jaringan. Kelengkapan Hardware mencakup processor, Random Access Memory (RAM), Harddisk, VGA Card, dan spesifikasi hardware lainnya. Sedangkan spesifikasi jaringan meliputi LAN, WAN, Tower dan Server. Data berikut ini akan memberikan gambaran tentang spesifikasi hardware dan jaringan yang digunakan Simda Kutai Kartanegara.

Hasil Penelitian menyebutkan bahwa mayoritas (51,3\%) pengguna Simda di Kabupaten Kutai Kartanegara menyebutkan bahwa kelengkapan hardware yang digunakan adalah cukup dan sangat lengkap. Sebagian pengguna Simda lainnya $(48,7 \%)$ menyatakan sebaliknya, yaitu kurang lengkap. Penggunaan Simda juga didorong oleh sikap dan perilaku pengguna yang tercermin dari rasa memiliki Simda dari para penggunanya.

Kurangnya optimalisasi Simda sejalan dengan persepsi para pengguna, yang beranggapan bahwa dukungan finansial dalam pemanfaatan Simda relatif masih kurang. Hal ini digambarkan oleh data berikut ini yang menyebutkan bahwa $46,2 \%$ pengguna merasa kurangnya dukungan finansial untuk pemanfaatan Simda. Meskipun demikian terdapat 35,3\% yang menyebutkan dukungan finansial untuk pemanfaatan Simda telah cukup besar, besar, dan sangat besar. Selain itu, juga tidak bisa diabaikan, bahwa terdapat 18,5\% yang secara ekstrim menyebutkan bahwa dukungan finansial untuk pemanfaatan Simda tidak ada sama sekali. 
Tabel 10. Strategi Perlindungan terhadap Simda

\begin{tabular}{lcccccc}
\hline \multirow{2}{*}{ Jangka Waktu } & & \multicolumn{3}{c}{ Peran dalam Simda } & \multirow{2}{*}{ Total } \\
\cline { 2 - 6 } Pemakaian UPS & & Administrator & Operator & Pengguna & \\
\hline \multirow{2}{*}{ Update Anti Virus Berkala } & $\%$ & 3 & $30.0 \%$ & $17.2 \%$ & 31 & 39 \\
\hline \multirow{2}{*}{ Strategi Lainnya } & $\%$ & $30.0 \%$ & $41.4 \%$ & $20.0 \%$ & $32.8 \%$ \\
\hline \multirow{2}{*}{ Jumlah } & $\mathrm{F}$ & 3 & 12 & 33 & 31 \\
\hline & $\%$ & $40.0 \%$ & $41.4 \%$ & $41.2 \%$ & $41.2 \%$ \\
\hline
\end{tabular}

Sumber: Hasil Pengolahan Data Primer, 2012

Dukungan terhadap optimalisasi penggunaan Simda juga dapat dilakukan dengan melakukan koordinasi dan evaluasi Simda, baik antar operator maupun administrator. Data berikut ini akan menggambarkan bahwa terdapat $37,8 \%$ responden yang menyatakan tidak ada rapat atau pertemuan koordinasi dan evaluasi terhadap peningkatan pemanfaatan Simda, baik antar operator maupun administrator. Meskipun demikian mayoritas pengguna telah melakukan koordinasi dan evaluasi, seperti temu operator dan administrator $(19,3 \%)$, sosialisasi Simda $(10,1 \%)$, evaluasi menyeluruh $(10,1 \%)$, dan koordinasi/evaluasi tidak rutin $(22,7 \%)$.

Terkait dengan munculnya masalah teknis dan nonteknis telah dilakukan berbagai strategi perlindungan terhadap aplikasi Simda. Beberapa strategi perlindungan yang teridentifikasi dari hasil penelitian adalah pemakaian UPS, update antivirus secara berkala dan strategi lainnya. Tabel 10 berikut ini akan menggambarkan sebaran penggunaan perlindungan Simda tersebut.

Strategi perlindungan Simda berdasarkan Tabel 11 memperlihatkan strategi yang paling banyak digunakan adalah penggunaan UPS $(32,8 \%)$, diikuti dengan strategi update anti virus secara berkala $(26,1 \%)$.

Dukungan terhadap implementasi Simda di Kabupaten Kutai Kartanegara pada dasarnya sudah cukup tinggi. Terutama dukungan dari hardware dan software Simda. Namun kelemahan terlihat dari jaringan dan kapasitas bandwidth yang terlalu kecil untuk jaringan tertentu. Hal ini dapat terjadi mengingat kendala jaringan yang sulit dengan karakteristik Kabupaten Kutai Kartanegara yang sangat luas dan berbukit. Akibatnya setting layout jaringan memerlukan kapasitas bandwidth yang besar. Saat ini sedang diusahakan untuk melakukan penambahan kapasitas bandwidth, di samping evaluasi terhadap layout jaringan, sehingga koneksitas antar SKPD dengan Pemda dapat optimal.
Software Simda diakui cukup bagus, namun cukup rentan dengan serangan virus. Masalah teknis dan non teknis paling banyak berasal dari software Simda yang terserang virus. Kabupaten Kutai Kartanegara mengoperasikan Simda melalui Windows (under windows). Hal inilah yang ditengarai sebagai penyebab seringnya software Simda menerima serangan virus. Usaha untuk perbaikan telah dilakukan baik oleh pemerintah daerah maupun oleh penyedia software Simda. Pemerintah Daerah saat ini sedang merencanakan untuk menggunakan software Simda dengan basis Linux, sehingga lebih aman dalam mengahadapi serangan virus.

\section{SIMPULAN}

Beberapa simpulan yang didapat dari hasil kajian ini, adalah sebagai berikut: pertama, Implementasi Simda di Kab. Kutai Kartanegara relatif telah cukup tinggi. Semua produk Simda dapat dilakukan di bawah rata-rata standard yang ditetapkan dalam Permendagri Nomor 13 Tahun 2006. Namun, produk Simda ini adalah produk parsial yang dihasilkan oleh Simda SKPD. Artinya, bukan produk lanjutan berupa LKPD yang dihasilkan oleh bagian keuangan sekretariat daerah. LKPD masih memerlukan proses lebih lanjut, berupa pengumpulan data dari seluruh SKPD termasuk sistem pertanggungjawaban keuangan lainnya seperti pengelolaan aset dan pengelolaan keuangan non kas.

Kedua, kesiapan sumber daya manusia dalam rangka implementasi Simda di Kabupaten Kutai Kartanegara relatif cukup baik. Kesimpulan ini dicerminkan dari:

a. Rata-rata pengalaman pengelola Simda yang cukup tinggi ( $>2$ tahun) dan pendidikan yang cukup tinggi (rata-rata S1).

b. Rata-rata pengetahuan pengelola mengacu pada tiga aspek implementasi Simda pada dua aspek relatif baik dan sangat baik, yaitu aspek penganggaran dan akuntansi serta pelaporan. Namun, dari aspek 
penatausahaan relatif tidak sebaik pengetahuan responden pada dua aspek lainnya.

Ketiga, terdapat empat bagian dalam setiap proses akuntansi dan pelaporan, yaitu akuntansi penerimaan dan pengeluaran kas, akuntansi aset, dan akuntansi selain kas. Dari ke empat bagian akuntansi tersebut, akuntansi aset adalah bagian yang paling rumit mengingat proses pekerjaannya bersifat kontinyu. Akuntansi aset inilah letak kelemahan Kabupaten Kutai Kartanegara. Perolehan predikat disclaimer lebih banyak disebabkan karena akuntansi aset, dipandang oleh BPK masih bermasalah.

Keempat, dukungan terhadap implementasi Simda di Kab. Kutai Kartanegara pada dasarnya sudah cukup tinggi. Terutama dukungan dari hardware dan software Simda. Beberapa kelemahan yang nampak dalam daya dukung implementasi Simda adalah:

a. Jaringan dan kapasitas bandwidth yang terlalu kecil untuk jaringan tertentu. Hal ini dapat terjadi mengingat kendala jaringan yang sulit dengan karakteristik Kabupaten Kutai Kartanegara yang sangat luas dan berbukit. Akibatnya setting layout jaringan memerlukan kapasitas bandwidth yang besar. Saat ini sedang diusahakan untuk melakukan penambahan kapasitas bandwidth, di samping evaluasi terhadap layout jaringan, sehingga koneksitas antar SKPD dengan Pemda dapat optimal.

b. Software Simda diakui cukup bagus, namun cukup rentan dengan serangan virus. Masalah teknis dan non teknis paling banyak berasal dari software Simda yang terserang virus. Kabupaten Kutai Kartanegara mengoperasikan Simda melalui Windows (under windows). Hal inilah yang ditengarai sebagai penyebab seringnya software Simda menerima serangan virus.

\section{Saran}

Beberapa saran untuk peningkatan implementasi Simda terkait dengan penelitian ini, antara lain: pertama, sumber daya manusia sebagai pendukung utama implementasi Simda, meski sudah cukup memadai perlu ditingkatkan, terutama dari aspek penatausahaan keuangan. Beberapa usaha peningkatan kualitas sumber daya manusia adalah dengan:

a. Semakin mengintensifkan koordinasi dan komunikasi antar pengelola Simda

b. Melakukan penempatan pegawai untuk tupoksi bidang keuangan yang sesuai dengan spesifikasi jabatan.

c. Menghindari mutasi pegawai pada bidang keuangan terutama pada bagian akuntansi aset pada bidang lainnya yang tidak terkait dengan bagian keuangan.

d. Menerapkan sistem rewards dan punishment khusus untuk pegawai yang mengelola Simda.
Kedua, dukungan terhadap implementasi Simda secara lebih optimal dapat dilakukan dengan cara:

a. Penyempurnaan layout jaringan perlu terus dilakukan, sebagai upaya penemuan layout jaringan yang mendukung perubahan dan peningkatan teknologi sistem informasi.

b. Penggunaan Simda berbasis Linux perlu dilakukan sebagai usaha untuk mencegah dan menanggulangi serangan virus.

c. Penambahan kapasitas bandwidth untuk jaringan tertentu, sebagai usaha untuk peanggulangan kendala geografis Kabupaten Kutai Kartanegara yang luas dan berbukit

\section{DAFTAR PUSTAKA}

PP No. 8 tahun 2006 tentang pelaporan keuangan dan kinerja Institusi Pemerintahan

PP No. 24 tahun 2005 tentang Standar Akuntansi Keuangan Pemerintahan

Peraturan Menteri Dalam Negeri No. 13 tahun 2006 tentang pedoman pengelolaan keuangan Pemerintah Daerah

Peraturan Menteri Dalam Negeri No. 59 tahun 2007 tentang pedoman pengelolaan keuangan Pemerintah Daerah

Peraturan Daerah Kabupaten Kutai Kartanegara No. 2 tahun 2005 tentang Pokok-pokok Keuangan Daerah

Peraturan Daerah Kabupaten Kutai Kartanegara Nomor 16 tahun 2006

Peraturan Daerah Kabupaten Kutai Kartanegara Nomor 12 tahun 2008;

Peraturan Daerah Kabupaten Kutai Kartanegara Nomor 15 tahun 2008;

Peraturan Daerah Kabupaten Kutai Kartanegara Nomor 16 tahun 2008;

Peraturan Bupati Kabupaten Kutai Kartanegara Nomor 1 Tahun 2012 tentang pengelolaan keuangan daerah.

C. Laudon, P. Jane Laudon, Kenneth. 2006. Management Information Systems.Pearson International.

Indrajit, Eko. R. 2006. Manajemen Sistem Informasi dan Teknologi Informasi. Elex Media Komputindo.

Mcleod, Raymond, Jr. 2006. Management Information Systems. Edisi Kedelapan. Prentice Hall.

Porter, Michael E. 2000. Competitive Strategy. The Free Press - A Division of Macmillan Publishers. London.

Romney, Marshall B, Steinbart, Paul J., and Cushing, Barry E. 2003. Accounting Information Systems. 10th edition. Addison Wesley, Reading Massachussets.

Ulrich Gelinas, Jr. dan Allan F. Oram. 2004. Accounting Information Sy 
282 | Jurnal Bina Praja | Volume 6 Nomor 4 Edisi Desember 2014: 269 - 282 